村瀬 篤 - 佐藤 紀夫

\title{
Continuous Devulcanization by Shear Flow Stage Reaction Control Technology for Rubber Recycling, Part 10. Rapid Identification of Waste Rubbers
}

\author{
Atsushi MURASE and Norio SATO (TOYOTA CENTRAL R\&D LABS., INC., Nagakute, Aichi, \\ 480-1192, Japan)
}

Pyrolysis infrared spectroscopy system using a pyrolysis probe has been developed for the rapid identification of waste rubbers containing a large amount of carbon black. This system consists of a pyrolysis probe, flexible and heatable gas guide, FT-IR, and computer. The small area of the surface of a plastic part is pyrolyzed momentarily with the pyrolysis probe, and the gaseous pyrolyzate is carried with nitrogen gas cell in FT-IR, the type of plastic is then identified with the IR spectra of the pyrolyzate. This method has the following features ; (1) Almost all kinds of waste rubbers used for automobile parts can be identified in a few seconds. (2)Samples do not need to be carried. (3)Surface degradation and stains do not affect the identification. And (4) automatic identification system using this technique has made it possible to identify rubbers by only one action. The application of this method to the identification of weather-strips which had been collected from scrapped cars has confirmed that this method is useful for sorting before devulcanization process of waste rubbers.

(Received on October 25, 1999)

Key Word : Recycle, Vulcanized rubber, Shear flow stage reaction control technology, Pyrolysis infrared spectroscopy, Identification

\section{1. 緒 言}

近年, 地球環境保全, 省資源化の観点から自動 車用樹脂・ゴム部品のリサイクルが強く求められ ている。加硫ゴムはタイヤ，ウェザーストリップ など自動車部品として多量に用いられており，リ サイクルの必要性が高い材料の一つである。しか し，架橋体であることからそのまま溶融・再成形

†本報を「せん断流動場反応制御技術によるゴムの連続再 生(第 10 報)」とする
することが不可能なため, 高品位なリサイクルが 困難な材料の一つとなっていた，著者らは，独自 に開発したせん断流動場反応制御技術によって加 硫ゴムの架橋点のみを選択的に切断する技術を開 発し，その結果，新材と同レベルの物性をもつ再 生ゴムを連続的に得ることが可能になった

この技術を廃車から回収したゴム部品の再生に 適用する場合には，ゴムの材質を迅速に識別する 技術が必要となる。例えばEPDM 製のウェザー ストリップをリサイクルする場合，廃車から回収 したウェザーストリップには EPDM 製以外に 
PVC 製のものも使われており，高品位な再生の ためには両者を分別する必要がある．現状は，解 体現場の作業者が製品の硬さの違いで分別してい るが，作業者の感覚に頼るために不正確となりが ちである。

従来，樹脂リサイクルのための高速識別技術と しては，近赤外透過法・拡散反射法，中赤外正反 射法などが提案されている ${ }^{2-5)}$ が，いずれも透明 なプラスチックボトルや，白をはじめとした明る い色の着色樹脂を対象としており，黒色がほとん どである加硫ゴムには適用不可能である。これに 対して著者らは，熱分解赤外分光法が顔料や充て ん剂の影響を受けることなくほぼすべての樹脂の 種類を識別できる ${ }^{6,7)}$ こと着目し，専用の熱分 解プローブを用いた熱分解ガス赤外分光型樹脂識 別装置の開発を進めてきた ${ }^{8)}$. 本装置は, 試料表 面を熱分解プローブを用いて瞬時に熱分解して, 発生した熱分解ガスの赤外スペクトルから樹脂の 種類を識別することを原理としている.

先の検討で，樹脂の熱分解赤外スペクトルが加 熱開始後数秒で得られること, 試料をもち運ぶこ となく部品そのままの任意の場所を測定できるこ と，更に黒を含む着色樹脂部品の識別に適してい ること，また表面の污れの影響を受けないことな どを確認した。しかし，ゴム材料のようにカーボ ンブラックが高度に充てんされた系，また複数の 化合物が混合された系に対する検出精度の解析 や，市場から回収されたゴム部品のように表面が 劣化したゴムに対しての解析は充分に行われてい なかった。そこで本研究では，自動車部品に使用 される代表的な実用ゴム材料および市場より回収 したゴム部品に対して，本識別法の可能性を検討 したので報告する。

\section{2. 実}

\section{験}

\section{1 識別装置}

本識別装置の概略を Fig. 1 に示す。本装置は, 試料表面を加熱して分解がスを発生させるための 熱分解プローブ，発生した分解ガスを窒素ガスに よってフーリ工変換赤外分光計 (FT-IR)のガス セルに導入するためのガスガイド，および分解ガ スの赤外スペクトルを測定するための FT-IR シ ステムの三つの部分から構成される.

熱分解プローブは当所で製作したもので，近赤 外線集光ランプを熱源にすることにより試料表面

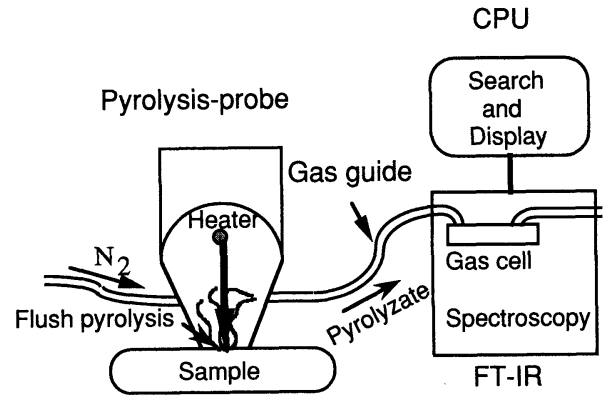

Fig. 1 Schematic drawing of identification system by pyrolysis IR.

の約 $5 \mathrm{~mm}$ 径の局所を 1 秒以内に分解温度以上 まで加熱することが可能となっているものであ る. FT-IR は日本電子製 JIR-100, 又は Nicolet 社製 Magna 750 を用いた。 ガスセルは GC-IR 用のライトパイプ (3 mm i.d., $400 \mathrm{~mm})$, 又は Harrick 社製加熱ガスセル $(20 \mathrm{~mm}$ i.d., $100 \mathrm{~mm})$ を用いた。熱分解時間は 2 秒, 窒素流量は $1 \mathrm{~L} /$ min, ガスガイドの温度は $150^{\circ} \mathrm{C}$, ガスセルの温 度は $200^{\circ} \mathrm{C} に$ 設定した。

\section{2 ゴム材料}

・ゴム平板：夕イヤ，ウェザーストリップなどの 自動車用ゴム部品に多用される代表的なゴムとし て，アクリロニトリルーブタジエンゴム (NBR), スチレンーブタジエンゴム $(\mathrm{SBR})$, エチレンープ ロピレンージエンターポリマー(EPDM)，および $\mathrm{NBR}$ と天然ゴム $(\mathrm{NR})$ とのブレンドを選択し, それらの平板(厚さ約 $2 \mathrm{~mm}$, カーボンブラック 約 30\%含有)を識別性能の評価に用いた。

・市場回収ゴム：市場回収ゴム部品として，使用 済み自動車より回収した EPDM 製および PVC 製のウェザーストリップ約 600 本を識別検討に供 した.これらは，日本自動車工業会と日本ゴム工 業会との共同研究において, 自動車用ゴム部品の リサイクル技術の検討を目的に回収したものであ $ろ^{9)}$.

\section{3 . 結果および考察}

\section{1 測定条件の検討}

熱分解時間を 2 秒，窒素流量を $1 \mathrm{~L} / \mathrm{min}$ にし た場合，熱分解開始直後からガスセル内の分解が ス濃度が上昇し, 約 5 秒で完全に排気されること が分かった。 ガスセル内の熱分解がスの濃度が最 


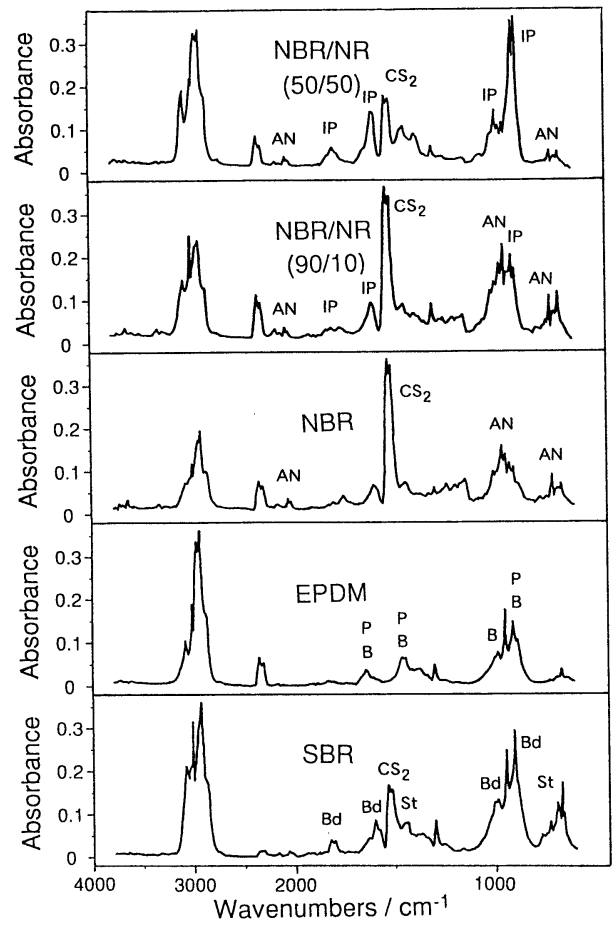

Fig. 2 IR spectra of gaseous pyrolyzates obtained by pyrolysis IR of three types of wide use rubber and blend rubbers, containing a large amount of carbon black.

Bd : Butadiene, St : Styrene, P : Propylene, B : Butene, AN : Acrylonitrile, IP : Isoprene

大となるのは加熱開始後 1 秒〜 3 秒であった. し たがって，この間に赤外測定するのが最も高速か つ高感度に赤外スペクトルを得ることができると 考之られる. 具体的には，熱分解開始 1 秒後に赤 外分析 (分解能 $8 \mathrm{~cm}^{-1}$, 積算回数 2 回, 測定時間 約 2 秒)を開始するのがゴムの識別に最適な条件 と考えられる。

また，発生する熱分解ガスは，モノマーやオリ ゴマー，又はそれらの熱変性したものが主体であ ク，常温では凝集するため，ガスの経路は常に加 熱する必要がある．特に，ガスガイドの温度が低 いと熱分解ガスがガスセルまで到達しない可能性 があり，ガスセルの温度が低いとセルの污染のた めに検出感度の低下とスペクトルの再現性の低下 が生じる。今回設定した条件 (ガスガイド $150^{\circ} \mathrm{C}$, ガスセル $\left.200^{\circ} \mathrm{C}\right)$ では，熱分解ガスの赤外スペク トルは識別に充分な強度で得られ，ガスセルの污 染も認められなかったことから，ゴムの識別に適

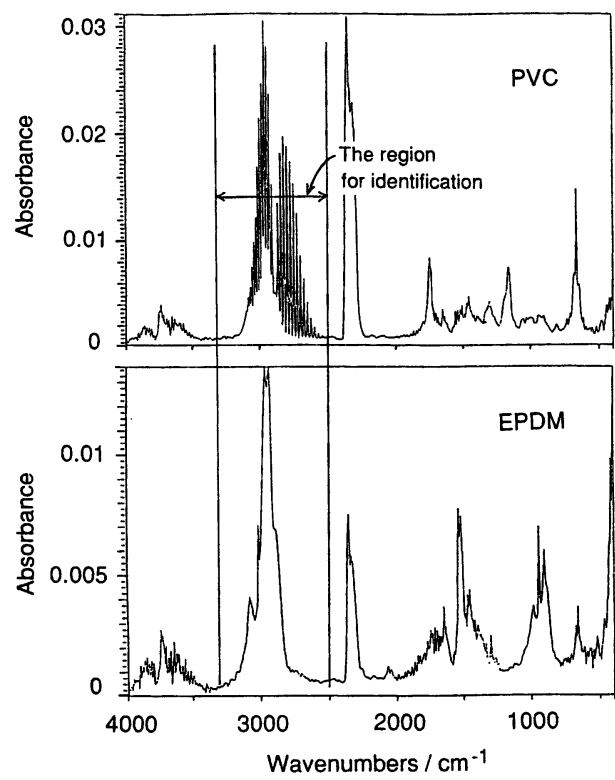

Fig. 3 IR spectra of gaseous pyrolyzates obtained by pyrolysis IR of two types of weather strip. Upper : PVC, Lower : EPDM

した条件と考えられる。

\section{2 ゴム平板試料の結果}

5 種類のゴムについて, 加熱開始 1 秒 3 秒後 に得られた熱分解ガスの赤外スペクトルを Fig. 2 に示す. SBR ではスチレンおよびブタジエン が，EPDMではプロピレンおよびブテンが, NBR ではアクリロニトリルが，各ゴムの主鎖の 構成二ニットに由来する熱分解生成物としていず れも識別に充分な強度で検出され，これらの赤外 スペクトルからゴムの種類が数秒で識別できるこ とが確認できた。各スペクトルに共通に見られる 二硫化炭素 $\left(\mathrm{CS}_{2}\right)$ は，ゴムの硫黄架橋又は加硫促 進剂などの硫黄系添加剂に由来するものと考えら れる.ゴムの種類によって相対強度が大きく異な ると考えられるが，同じ種類のゴムで比較した場 合には架橋状態の評価に利用できる可能性があ る。なお，これらのスペクトルでは， $\mathrm{CS}_{2}$ および 熱分解時に発生する $\mathrm{CO}_{2}$ と $\mathrm{H}_{2} \mathrm{O}$ 以外はゴムの骨 格に由来する成分のみ検出されており, 少量 ( 1 \%以下)添加されている老化防止剂などは検出さ れていない.したがって，これらの配合剂の組成 は識別結果に影響しないものと考えられる。

また，NBR と NR とのブレンドでは，NBR 


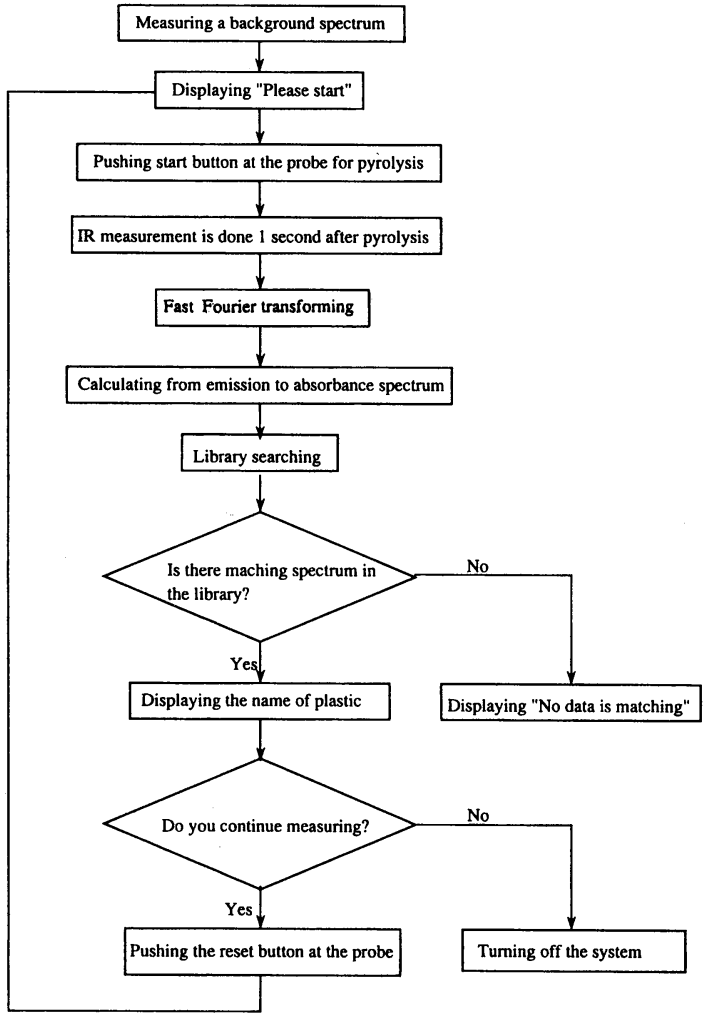

Fig. 4 Flow chart for the automatic identification system.

の主鎖構成ユニットに由来するアクリロニトリル に加えてNRの主鎖ユニットに由来するイソプ レンが認められ，NRの混合比率に比例して相対 量が多くなっているのが確認された。したがっ て，イソプレンとアクリロニトリルとの比率を 種々の混合比率のブレンドゴムに対して求めてお き，検量線を作成することによってブレンド比の 高速評価も可能であることが分かった。

\section{3 市場回収ゴムの結果}

市場より回収したウェザーストリップゴムのう ち, $\mathrm{EPDM}$ 製と PVC 製の物の熱分解赤外スぺ クトルを Fig. 3 に示す。この図から，PVC 製で は $3300 \mathrm{~cm}^{-1} \sim 2500 \mathrm{~cm}^{-1}$ にPVC 特有の熱分解 生成物である塩化水素がスの吸収が明瞭に現れて おり，この波数範囲で EPDM とは明らかに区別 できることが分かった.

試料の表面は煤などで污染しているものが多 く, $2300 \mathrm{~cm}^{-1}$ の $\mathrm{CO}_{2}$ の吸収強度に対して影響

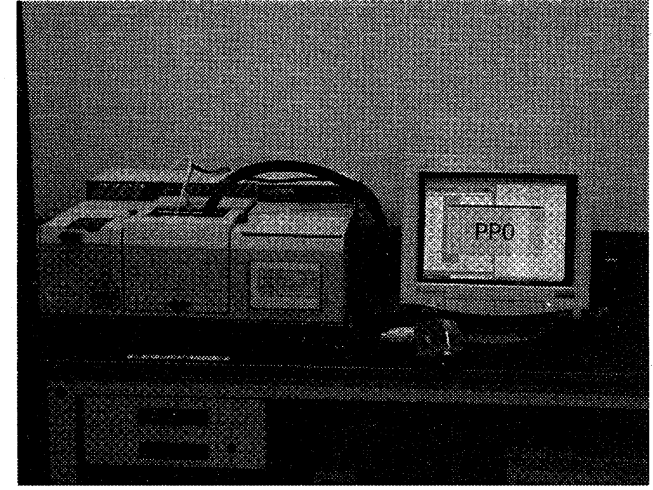

Fig. 5 An example of automatic identification system.

が見られたが，ここでの識別波数範囲では污染の 影響は見られなかった。また，表面の劣化はスぺ クトルに全く影響を及ぼさなかった。

\section{4 自動識別装置の試作}

・装置概要：前項までの結果から，熱分解プロー ブを用いた熱分解赤外分光法によって，カーボン ブラックを多量に含んだ加硫ゴムの種類が数秒で 識別できることを確認した。しかし，この技術を 解体工場やリサイクル工場などで利用するために は，操作がより簡便であることと，更に分析技術 者でなくても間違いなく識別できることが必要で ある。そこで，Fig. 4 に示すフローチャートを作 成し，それに基づいて自動識別装置を試作した。 すなわち，バックグラウンドスペクトルを測定し た後スタートボタンを押すと，熱分解一赤外測定 を連続して行い，更に得られた赤外スペクトルを あらかじめ登録しておいた標準材料の赤外スぺク トルとコンピュータ上で自動的に照合し，スぺク トルパターンが $80 \%$ 以上一致したもののなかか ら最も一致度の高いスペクトルの材料名を CRT に表示するものである。自動識別装置の外観を Fig. 5 に示す。これにより，熱分解プローブに取 り付けたスタートスイッチを押すだけで，熱分解 から結果表示までを自動的に行うことができるよ うになった．代表的な自動車用樹脂を用いて試し たところ，スタートスイッチを押してから結果が 表示されるまでの時間は約 5 秒であった。

・市場回収ウェザーストリップ 600 本の識別： EPDM 製と PVC 製とが混在した市場回収ウェ ザーストリップを本自動識別装置によって識別し た結果， 600 本すべての識別・分別が短時間で完 
了し，正解率は 100\%であった。

\section{4. 結}

\section{論}

1 ) ゴムの連続再生技術の一環として，加硫ゴム の識別技術を検討し，専用プローブを用いた熱分 解ガス赤外分光型樹脂識別装置が加硫ゴムの識別 に適していることを確認した，本装置により，従 来測定困難だったカーボンブラック入りの加硫ゴ 么廃材の材質が，切り出しや表面研磨などの前処 理を行うことなく， 5 秒以内で $100 \%$ の確度で識 別ができた。

2 ) 本識別装置を自動化することにより，分析経 験のない作業者でも利用できるようになった。

3 ) 自動化した識別装置を用いて，使用済み自動 車から回収したウェザーストリップ 600 本の識別 を行ったところ，表面の污染や劣化の影響を受け ることなく $\mathrm{EPDM}$ 製と $\mathrm{PVC}$ 製とが明瞭に識別 でき，全数の識別・分別が短時間で完了した。

\section{謝 辞}

自動識別装置の開発において御協力いただいた ニコレージャパン(珠)，および熱分解プローブの設
計・試作において御協力いただいた侏豊田中央研 究所の松井正行技師に感謝いたします。

\section{引用 文 献}

1）毛利 誠，佐藤紀夫，岡本浩孝，松下光正，本多秀 亘, 中島克己, 竹内勝政, 鈴木康之, 大脇雅夫：日ゴ 么協誌，72，81(1999)

2 ) Willenberg, B., Kohn, W., Ritzmann, H. : Plastverarbeiter, 44, 21 (1993)

3 ) Vornberger, K., Willenberg, B. : Kunststoffe Plast Europe, 84, March (1994)

4) Jansen, J.A.J., Haas, W.E. : Polymer Commun., 29, 77 (1988)

5 ) Jansen, J.A.J., Hastenberg, C.H.V. : Kunststoffe, 84, 51(1994)

6 ）石黒昌孝, 松岡千恵子, 中津 純：関税中央分析所 報，第 27 号，179(1987)

7) Davidson, R.G. :J. Anal. Appl. Pyrolysis, 16, 143(1989)

$8)$ Murase, A., Sato, N.: Applied Spectroscopy, 53, $745(1999)$

9 ）河西純一, 猪飼忠義, 杉本正俊, 濱田 裕, 加藤公 一, 里田秀敏：自動車技術会学術講演会前刷集, No. 42-99, 9(1999) 